\title{
FAKTOR-FAKTOR KUALITAS PEMERIKSAAN PADA PERUM BULOG DIVISI REGIONAL SUMATERA UTARA
}

\author{
M. Firza Alpi $a^{*}$, \\ ${ }^{a}$ Universitas Muhammadiyah Sumatera Utara
}

Diterima Juni 2019; Disetujui Agustus 2019; Dipublikasikan November 2019

\begin{abstract}
Abstrak
Penelitian ini bertujuan untuk mengetahui Pengaruh objektivitas, kompetensi, pengalaman, intergritas dan akuntabilitas terhadap kualitas pemeriksaan pada perum bulog divisi regional sumatera utara, dan mengetahui dan menganalisis Pengaruh objektivitas, kompetensi, pengalaman, intergritas dan akuntabilitas terhadap kualitas pemeriksaan pada perum bulog divisi regional sumatera utara Penelitian ini mengunakan jenis penelitain asosiatif. Penelitian ini dilakukan pada perum bulog divisi regional sumatera utara. Populasi yang digunakan dalam penelitian ini adalah seluruh Karyawan perum bulog divisi regional sumatera utara (Audit Internal). Sampel yang diambil dalam penelitian ini ada 41 sampel data sensus pada perum bulog divisi regional sumatera utara. Dalam penelitian ini model dan teknik analisa data menggunakan pendekatan regresi linier berganda. Hasil penelitian menunjukkan bahwa nilai kompetensi menunjukkan tingkat signifikansi 0,001, Integritas menunjukkan nilai signifikansi 0,009 dan akuntabilitas sebesar 0,003 dimana tiga variable tersebut lebih kecil dari 0,05 yang secara parsial variabel berpengaruh signifikan terhadap Kualitas Pemeriksaan pada Perum Bulog Divisi Regional Sumatera Utara. Variable lain yang tidak disebutkan tidak berpengaruh secara parsial atas kualitas pemeriksaan.
\end{abstract}

Kata Kunci: Objektivitas, Kompetensi, Pengalaman , Intergritas, Akuntabilitas, Kualitas Pemeriksan

\begin{abstract}
This study aims to determine the influence of objectivity, competence, experience, integrity and accountability on the quality of examinations in the Perum Bulog, this study is also to know and analyze the influence of objectivity, competence, experience, integrity and accountability on the quality of examinations the Perum Bulog. This research uses associative research. The population used in this study were all employees of Internal Audit Perum Bulog. The sample taken in this study was 41 from census data on Perum Bulog. In this study data analysis models and techniques use a multiple linear regression approach. The results showed that the competency value showed a significance level of 0.001, Integrity showed a significance value of 0.009 and accountability of 0.003 where the three variables were smaller than 0.05 which partially had a significant effect on the Quality of Examination at the Perum Bulog. Other variable have no partial effect on the quality of the examination.
\end{abstract}

Keyword: Objectivity, Competence, Experience, Intergrity, Accountability, Quality of Distribution

How To Cite: Alpi, M. Firza (2019) Faktor-Faktor Kualitas Pemeriksaan Pada Perum Bulog Divisi Regional Sumatera Utara. Jurnal Akuntansi dan Bisnis: Jurnal Program Studi Akuntansi, 5 (2): 129 - 138

* email: m.firzaalpi@umsu.ac.id

\section{PENDAHULUAN}

Perusahaan Umum Badan Urusan Logistik atau disingkat Perum Bulog, sebagai salah satu perusahaan BUMN memegang peranan penting dalam mengelola stabilitas ketahanan komoditas pangan strategis di Indonesia, khususnya komoditas beras 
(Wijayanti, S. 2011). Komoditas pangan strategis adalah berbagai jenis komoditas atau produk yang dibutuhkan seluruh kalangan masyarakat di Indonesia yang dianggap penting oleh Pemerintah Indonesia, seperti: beras, tepung, jagung, kedelai, gula pasir, minyak goreng, dan daging sapi. Sehingga stabilitas keberadaannya menjadi tanggung jawab Pemerintah Indonesia. Perum Bulog dibentuk pada tanggal 10 Mei 1967 berdasarkan keputusan Presidium Kabinet Nomor 114/Kep/1967. Sejak tahun 2003, status Bulog menjadi BUMN. Faktor lainnya yang dapat berpengaruh terhadap kualitas pemeriksaan adalah akuntabilitas. Akuntabilitas merupakan sebagai bentuk dorongan psikologi yang membuat seseorang berusaha mempertanggungjawabkan semua tindakan dan keputusan yang diambil kepada lingkungannya. Lingkungan disini maksudnya adalah lingkungan atau tempat dimana seseorang melakukan aktivitas atau pekerjaannya yang dapat memengaruhi keadaan di sekitarnya (Suyanti, 2015). Realita empiris menunjukkan bahwa masih terdapat temuan audit oleh Badan Pemeriksa Keuangan (BPK) sebagai auditor eksternal pemerintah terhadap Perum Bulog hingga tahun 2016. Selain itu, tindak lanjut atas temuan tersebut belum sepenuhnya dapat diselesaikan oleh Perum Bulog. Hal tersebut dapat dilihat dari Tabel 1 berikut ini:

Tabel 1 Temuan Audit BPK \& Tindak Lanjut atas Temuan Hingga Tahun 2016 Perum Bulog Divisi Regional Sumatera Utara

\begin{tabular}{ccccccc}
\hline & & & \multicolumn{3}{c}{ Hasil pemantauan tindak lanjut } \\
\cline { 5 - 6 } Entitas & $\begin{array}{c}\text { Jumlah } \\
\text { Temuan }\end{array}$ & $\begin{array}{c}\text { Jumlah } \\
\text { Rekomendasi }\end{array}$ & Selesai & $\begin{array}{c}\text { Belum } \\
\text { Selesai }\end{array}$ & $\begin{array}{c}\text { Belum } \\
\text { Ditindak } \\
\text { Lanjuti }\end{array}$ & $\begin{array}{c}\text { Tidak Dapat } \\
\text { Ditindak Lanjuti }\end{array}$ \\
\hline $\begin{array}{l}\text { Perum Bulog } \\
\text { Divre Sumut }\end{array}$ & 11 & 24 & 17 & 4 & 2 & 1 \\
\hline
\end{tabular}

Berdasarakan Tabel 1 dapat dilihat khusus untuk Perum Bulog Divisi Regional Sumatera Utara, terdapat 11 jumlah temuan audit BPK hingga tahun 2016. Sementara itu terdapat 24 rekomendasi yang diberikan dengan rincian 17 rekomendasi telah selesai dilaksanakan, 4 rekomendasi belum selesai dilaksanakan, 2 rekomendasi belum ditindak lanjuti, dan 1 rekomendasi tidak dapat ditindak lanjuti. Dari fenomena di atas, dapat dilihat adanya indikasi permasalahan yang ada di Perum Bulog Divisi Regional Sumatera Utara, yaitu masih terdapat temuan audit BPK hingga tahun 2016 seperti proses distribusi barang tidak sesuai dengan prosedur yang ada, kemudian perencanaan kebutuhan operasional tidak tepat sasaran. Selain itu, tidak semua rekomendasi BPK dapat dilaksanakan oleh Perum Bulog, baik dalam skala nasional maupun pada Divisi Regional Sumatera Utara. Indikasi permasalahan yang dapat dilihat ialah masih belum optimalnya fungsi audit internal di Perum Bulog. Hal ini dikarenakan apabila kualitas pemeriksaaan yang dilakukan oleh internal auditor telah berjalan dengan baik, maka diharapkan secara ideal tidak ada lagi temuan audit yang didapatkan oleh BPK. Selain itu, seluruh rekomendasi hasil audit BPK semestinya dapat diselesaikan oleh internal Perum Bulog Divisi Regional Sumatera Utara.

\section{Kualitas Pemeriksaan}

Mulyadi (2002) mengatakan bahwa pemeriksaan audit adalah suatu proses sistematik untuk memperoleh dan mengevaluasi bukti secara objektif mengenai pernyataan-pernyataan tentang kegiatan dan kejadian ekonomis, dengan tujuan untuk menetapkan tingkat kesesuaian antara pernyataan- pernyataan tersebut dengan kriteria yang telah ditetapkan serta penyampaian hasil- hasil kepada pemakai yang berkepentingan. Berdasarkan pengertian mengenai audit tersebut dapat kita simpulkan 
bahwasanya audit merupakan proses sistematik yang dilakukan oleh seorang yang independen dan kompeten dalam melakukan pemeriksaan dan memberikan opini terhadap kewajaran dari laporan audit tersebut. Kualitas hasil pemeriksaan adalah probabilitas dimana seorang auditor menemukan dan melaporkan tentang adanya suatu pelanggaran dalam sistem akuntansi kliennya. KAP yang besar akan berusaha untuk menyajikan kualitas hasil pemeriksaan yang lebih besar dibandingkan dengan KAP yang kecil (Alim dkk., 2007).

\section{Objektivitas}

Objektivitas adalah suatu keyakinan, kualitas yang memberikan nilai bagi jasa atau pelayanan auditor. Objektivitas merupakan salah satu ciri yang membedakan profesi akuntan dengan profesi yang lain. Prinsip objektivitas menetapkan suatu kewajiban bagi auditor (akuntan publik) untuk tidak memihak, jujur secara intelektual, dan bebas dari konflik kepentingan (Wayan, 2005).Menurut Wibowo (2006) auditor menunjukkan objektivitas profesional pada tingkat yang tertinggi ketika mengumpulkan, mengevaluasi, dan melaporkan informasi kegiatan atau proses yang sedang diuji. Auditor melakukan penilaian yang seimbang atas semua kondisi yang relevan dan tidak terpengaruh oleh kepentingannya sendiri atau kepentingan orang lain dalam membuat keputusannya.

\section{Kompetensi}

Standar Umum pertama (SA seksi 210 dalam SPAP, 2001) menyebutkan bahwa audit harus dilaksanakan oleh seorang atau yang memiliki keahlian dan pelatihan teknis yang cukup sebagai auditor. Sedangkan, standar umum ketiga (SA seksi 230 dalam SPAP, 2001) menyebutkan bahwa dalam pelaksanaan audit akan penyusunan laporannya, auditor wajib menggunakan kemahiran profesionalnya dengan cermat dan saksama. Oleh karena itu, maka setiap auditor wajib memiliki kemahiran profesionalitas dan keahlian dalam melaksanakan tugasnya sebagai auditor. Kompetensi merupakan pengetahuan, keterampilan, dan kemampuan yang berhubungan dengan pekerjaan, serta kemampuan yang dibutuhkan untuk pekerjaan-pekerjaan non-rutin.

Dalam melakukan audit, seorang auditor harus memiliki mutu personal yang baik, pengetahuan yang memadai, serta keahlian khusus di bidangnya. Kompetensi berkaitan dengan keahlian profesional yang dimiliki oleh auditor sebagai hasil dari pendidikan formal, ujian profesional maupun keikutsertaan dalam pelatihan, seminar, simposium (Suraida, 2005).

\section{Integritas}

Menurut Arens (2008), integritas berarti bahwa bahwa seseorang bertindak sesuai dengan kata hatinya, dalam situasi seperti apapun. Sedangkan menurut Mulyadi (2002), integritas adalah suatu karakter yang menunjukan kemampuan seseorang untuk mewujudkan apa yang telah disanggupinya dan diyakini kebenarannya kedalam kenyataan. Auditor yang berintegritas adalah auditor yang memiliki kemampuan untuk mewujudkan apa yang telah diyakini kebenarannya tersebut ke dalam kenyataan. Menurut Sukrisno (2004), integritas adalah unsur karakter yang mendasar bagi pengakuan profesional. Integritas merupakan kualitas dalam menguji semua keputusannya. 


\section{Akuntabilitas}

Istilah akuntabilitas berasal dari Bahasa Inggris "accountability" yang memiliki arti pertanggungjawaban atau keadaan untuk dipertanggung jawabkan atau keadaan untuk diminta pertanggung jawaban. Tetlock (1984) mendefinisikan akuntabilitas sebagai bentuk dorongan psikologi yang membuat seseorang berusaha mempertanggung jawabkan semua tindakan dan keputusan yang diambil kepada lingkungannya. Peran dan tanggung jawab auditor diatur dalam Standar Profesional Akuntan Publik (SPAP) yang ditetapkan oleh IAI ataupun Statement on Auditing Standards (SAS) yang dikeluarkan oleh Auditing Standards Board (ASB).

\section{Pengaruh Objektifitas terhadap Kualitas Pemeriksaan}

Objektivitas merupakan suatu ciri yang membedakan profesi akuntan dengan profesi-profesi yang lain. Prinsip objektivitas menetapkan suatu kewajiban bagi auditor untuk tidak memihak, jujur secara intelektual, dan bebas dari konflik kepentingan.Pemeriksa harus mempertahankan objektivitas pada saat melaksanakan pemeriksaan untuk mengambil keputusan yang konsisten dengan kepentingan publik. Objektivitas auditor merupakan dasar utama kepercayaan masyarakat terhadap perkembangan profesi dan prasyarat yang sangat penting dalam penilaian kualitas hasil kerja auditor. Sukriah dkk (2009) menyatakan bahwa semakin tinggi tingkat obyektifitas auditor maka semakin baik kualitas hasil pemeriksaannya. Dengan kata lain, semakin tinggi tingkat objektifitas auditor maka semakin baik kualitas hasil pemeriksaannya.

\section{Pengaruh Objektifitas terhadap Kualitas Pemeriksaan}

Objektivitas merupakan suatu ciri yang membedakan profesi akuntan dengan profesi-profesi yang lain. Prinsip objektivitas menetapkan suatu kewajiban bagi auditor untuk tidak memihak, jujur secara intelektual, dan bebas dari konflik kepentingan.Pemeriksa harus mempertahankan objektivitas pada saat melaksanakan pemeriksaan untuk mengambil keputusan yang konsisten dengan kepentingan publik. Objektivitas auditor merupakan dasar utama kepercayaan masyarakat terhadap perkembangan profesi dan prasyarat yang sangat penting dalam penilaian kualitas hasil kerja auditor. Sukriah dkk (2009) menyatakan bahwa semakin tinggi tingkat obyektifitas auditor maka semakin baik kualitas hasil pemeriksaannya. Dengan kata lain, semakin tinggi tingkat objektifitas auditor maka semakin baik kualitas hasil pemeriksaannya.

\section{Pengaruh Pengalaman terhadap Kualitas Pemeriksaan}

Sesuai dengan standar umum dalam Standar Profesional Akuntan Publik bahwa auditor disyaratkan memiliki pengalaman kerja yang cukup dalam profesi yang ditekuninya, serta dituntut untuk memenuhi kualifikasi teknis dan berpengalaman dalam bidang industri yang digeluti kliennya (Arens dkk., 2004). Pengalaman akuntan akan terus meningkat seiring dengan makin banyaknya audit yang dilakukan serta kompleksitas transaksi keuangan perusahaan yang diaudit sehingga akan menambah dan memperluas pengetahuannya di bidang akuntansi dan auditing (Christiawan, 2002).

\section{Pengaruh Integritas terhadap Kualitas Pemeriksaan}

Kode Etik Akuntan Indonesia pasal 1 ayat dua menyatakan bahwa setiap auditor harus mempertahankan integritas, objektivitas dan independensi dalam melaksanakan tugasnya. Seorang auditor yang mempertahankan integritas akan bertindak jujur dan tegas dalam memertimbangkan fakta, terlepas dari kepentingan pribadi. Dalam hal ini auditor dituntut untuk bertindak jujur dan tegas dalam mengungkapkan semua bukti 
audit yang sesuai dengan keadaan yang sebenarnya tanpa dipengaruhi oleh pihak- pihak yang dapat menganggu integritas pribadi auditor. Sehingga kualitas pekerjaan auditor dapat dipercaya oleh publik sesuai dengan tatanan nilai tertinggi bagi anggota profesi, karena pada dasarnya integritas menjadi salah satu jaminan kualitas dalam menilai hasil kerja auditor.

Sunarto (2003) menyatakan bahwa integritas dapat menerima kesalahan yang tidak disengaja dan perbedaan pendapat yang jujur, tetapi tidak dapat menerima kecurangan prinsip. Dengan integritas yang tinggi maka kualitas hasil kerja auditor semakin baik.

\section{Pengaruh Akuntabilitas terhadap Kualitas Pemeriksaan}

Akuntabilitas adalah rasa kebertanggungjawaban yang dimiliki oleh auditor dalam menyelesaikan pekerjaan audit. Akuntabilitas merupakan dorongan psikologi sosial yang dimiliki seseorang untuk menyelesaikan kewajibannya yang akan dipertanggungjawabkan kepada lingkungan. Seseorang yang memiliki akuntabilitas tentunya akan bertanggung jawab kepada hasil pekerjaan auditor sehingga akuntabilitas akan mempengaruhi pekerjaan seseorang.

Semakin tinggi akuntabilitas yang dimiliki oleh auditor maka bisa dipastikan kualitas audit yang dihasilkan dapat dipertanggungjawabkan sehingga laporan keuangan yang diaudit dan laporan hasil audit yang dihasilkan memberikan kepercayaan dan keandalan bagi pengguna laporan keuangan dalam mengambil keputusan

\section{METODE PENELITIAN}

Penelitian ini menggunakan pendekatan penelitian asosiatif, yang bertujuan untuk memecahkan dan menjawab permasalahan yang dihadapi pada situasi sekarang, metode ini dilakukan dengan menempuh langkah-langkah pengumpulan klasifikasi dan analisis atau pengolahan data, membuat kesimpulan dan harapan dengan tujuan utama membuat gambaran tentang atau keadaaan secara objektif.

\section{Jenis dan Sumber Data}

Jenis data yang digunakan dalam penelitian ini adalah data primer. Sumber data dalam penelitian ini adalah auditor yang terdapat di Bulog Divisi Regional Sumatera Utara melalui kuesioner yang dibagikan pada saat penelitian. . Data diperoleh dengan menggunakan daftar pertanyaan yang tercantum secara terstruktur di dalam kuesioner dengan tujuan untuk mengumpulkan informasi dari auditor yang berkerja di Bulog Divisi Regional Sumatera Utara sebagai responden dalam penelitian.

Populasi adalah jumlah dari keseluruhan objek yang karakteristiknya hendak diduga. Populasi juga merupakan keseluruhan kumpulan elemen-elemen berkaitan dengan apa yang peneliti harapkan dalam mengambil beberapa kesimpulan (Ikhsan dkk, 2014). Populasi yang digunakan pada penelitian ini adalah auditor yang berjumlah 41 orang Auditor. Sampel adalah bagian dari populasi atau yang mewakili untuk diteliti. Dalam penelitian ini, seluruh populasi akan dijadikan sampel penelitian sehingga penentuan sampel menggunakan metode sensus.

\section{Metode Analisis}

Teknik analisis data dalam penelitian ini yaitu berupa teknik analisis yang terdiri dari uji hipotesis terdiri dari uji parsial (uji t) dan uji simultan (Uji F). 


\section{HASIL DAN PEMBAHASAN}

Tabel 2 berikut menunjukkan hasil uji parsial (uji t) yang dilakukan:

Tabel 2 Uji Parsial

\begin{tabular}{cccccc}
\hline & \multicolumn{2}{c}{$\begin{array}{l}\text { Unstandardized } \\
\text { Coefficients }\end{array}$} & $\begin{array}{c}\text { Standardized } \\
\text { Coefficients }\end{array}$ & & \\
\cline { 2 - 5 } & $\mathrm{B}$ & Std. Error & Beta & $\mathrm{t}$ & Sig. \\
\hline Constant & 1.390 & .992 & & 1.994 & .027 \\
OBJEKTIFITAS & .368 & .116 & .456 & 3.165 & .003 \\
KOMPETENSI & .144 & .131 & .156 & 1.095 & .001 \\
PENGALAMANAUDIT & .064 & .055 & .072 & 1.177 & .247 \\
INTEGRITAS & .597 & .113 & .745 & 5.295 & .009 \\
AKUNTABILITAS & .610 & .135 & .644 & 4.527 & .003 \\
\hline
\end{tabular}

Dari Tabel 2 dapat diketahui bahwa nilai signifikan variabel Objektifitas lebih kecil dari 0,05. Skeptisme menunjukkan nilai signifikansi 0,003 (Sig $=0,000<0,05$ ) sehingga secara parsial variabel skeptisme berpengaruh positif dan signifikan terhadap Kualitas Pemeriksaan pada Perum Bulog Divisi Regional Sumatera Utara. Nilai signifikan variabel Kompetensi lebih kecil dari 0,05. Kompetensi menunjukkan nilai signifikansi 0,001 (Sig $=0,001<0,05$ ) sehingga secara parsial variabel Kompetensi berpengaruh signifikan terhadap Kualitas Pemeriksaan pada Perum Bulog Divisi Regional Sumatera Utara. Nilai signifikan variabel Pengalaman Audit lebih besar dari 0,05. Pengalaman Audit menunjukkan nilai signifikansi 0,247 (Sig $=0,247>0,05)$ sehingga secara parsial variabel Pengalaman Audit tidak berpengaruh terhadap Kualitas Pemeriksaan pada Perum Bulog Divisi Regional Sumatera Utara. Nilai signifikan variabel Integritas lebih kecil dari 0,05. Integritas menunjukkan nilai signifikansi 0,009 ( $\mathrm{Sig}=0,009<0,05$ ) sehingga secara parsial variabel Integritas berpengaruh signifikan terhadap Kualitas Pemeriksaan pada Perum Bulog Divisi Regional Sumatera Utara. Nilai signifikan variabel Akuntabilitas lebih kecil dari 0,05. Integritas menunjukkan nilai signifikansi 0,003 (Sig =0,003<0,05) sehingga secara parsial variabel Akuntabilitas berpengaruh signifikan terhadap Kualitas Pemeriksaan pada Perum Bulog Divisi Regional Sumatera Utara. Uji Statistik F pada dasarnya menunjukkan apakah semua variabel independen yang dimasukkan dalam model mempunyai pengaruh secara simultan terhahap variabel dependen Adapun untuk pengujian hipotesis secara simultan dapat ditunjukkan melalui Tabel 3 sebagai berikut:

Tabel 3 Uji Simultan

\begin{tabular}{cccccc}
\hline Model & Sum of Squares & df & Mean Square & F & Sig. \\
\hline Regression & 2.829 & 5 & .566 & 52.085 & $.000^{\mathrm{b}}$ \\
Residual & .380 & 35 & .011 & & \\
Total & 3.209 & 40 & & & \\
\hline
\end{tabular}

Berdasarkan Tabel 3 diketahui bahwa nilai signifikan bernilai 0,000 dimana nilai tersebut lebih kecil dari 0,05 (Sig = 0,000 < 0,05) sehingga dapat disimpulkan bahwa secara simultan variabel Objektivitas, Kompetensi, Pengalaman Audit, Integritas dan Akuntabilitas berpengaruh sigmifikan terhadap Kualitas Pemeriksaan pada Perum Bulog Divisi Regional Sumatera Utara.

\section{Pengaruh Objektivitas terhadap Kualitas Pemeriksaan}

Hasil analisis regresi menunjukkan bahwa nilai koefisien regresi variabel objektivitas adalah 0,368 artinya setiap kenaikan variabel objektivitas maka Kualitas 
Pemeriksaan akan meningkat sebesar 36,8\% dengan asumsi variabel lainnya dianggap konstan serta signifikansi variabel objektivitas menunjukkan nilai signifikansi 0,003 (Sig $=0,003<0,05$ ) sehingga secara parsial variabel objektivitas berpengaruh terhadap Kualitas Pemeriksaan pada Perum Bulog Divisi Regional Sumatera Utara.Hasil ini sejalan dengan teori yang menyatakan bahwa objektivitas berpengaruh terhadap kualitas pemeriksaan. Implikasi yang dapat dilakukan oleh manajemen terhadap hasil penelitian ini yaitu bahwa untuk meningkatkan kualitas pemeriksaan pada Perum Bulog Divisi Regional Sumatera Utara, maka faktor objektivitas hendaknya ditingkatkan antara lain melalui penerapan kode etik yang mencakup objektivitas secara konsisten berkesinambungan oleh auditor.

\section{Pengaruh Kompetensi terhadap Kualitas Pemeriksaan}

Hasil analisis regresi menunjukkan bahwa nilai koefisien regresi variabel kompetensi adalah 0,144 artinya setiap kenaikan variabel kompetensi maka Kualitas Pemeriksaan akan meningkat sebesar 14,4\% dengan asumsi variabel lainnya dianggap konstan serta signifikansi variabel kompetensi menunjukkan nilai signifikansi 0,001 (Sig $=0,001<0,05$ ) sehingga secara parsial variabel kompetensi berpengaruh signifikan terhadap Kualitas Pemeriksaan pada Perum Bulog Divisi Regional Sumatera Utara.Hasil tersebut selaras dengan teori yang ada dimana kompetensi bepengaruh terhadap kualitas pemeriksaan. Dampak dari hasil penelitian ini dapat diimplementasikan yaitu untuk meningkatkan kualitas pemeriksaan pada Perum Bulog Divisi Regional Sumatera Utara maka dapat dilakukan dengan meningkatkan kompetensi auditor melalui bentuk pendidikan dan pelatihan yang dilakukan secara kontinu.

\section{Pengaruh Pengalaman Audit terhadap Kualitas Pemeriksaan}

Hasil analisis regresi menunjukkan bahwa nilai koefisien regresi variabel pengalamn audit adalah 0,064 artinya setiap kenaikan variabel pengalaman audit maka Kualitas Pemeriksaan akan meningkat sebesar 6,4\% dengan asumsi variabel lainnya dianggap konstan serta signifikansi variabel kompetensi menunjukkan nilai signifikansi 0,247 (Sig $=0,247>0,05$ ) sehingga secara parsial variabel pengalaman audit tidak berpengaruh terhadap Kualitas Pemeriksaan pada Perum Bulog Divisi Regional Sumatera Utara.Hasil penelitan ini tidak sejalan dengan teori yang menyatakan bahwa pengalaman audit berpengaruh terhadap kualitas pemeriksaan. Adapun argumen yang dapat mendukung hasil penelitian ini bahwa Inspektorat Kabupaten Samosir telah memiliki Standar Operasional Prosedur (SOP) yang memadai terhadap segala Tugas Pokok dan Fungsi (Tupoksi) yang harus dilaksanakan oleh seorang auditor pada berbagai kondisi yang dihadapi. Hal ini berimplikasi kepada auditor, dimana dengan adanya SOP yang memadai di setiap tahapan audit yang dilaksanakan maka auditor tidak mengalami kesulitan berarti yang dapat mempengaruhi kualitas auditnya, meskipun pengalaman auditor yang satu lebih rendah dibandingkan pengalaman auditor yang lainnya.

\section{Pengaruh Integritas terhadap Kualitas Pemeriksaan}

Hasil analisis regresi menunjukkan bahwa nilai koefisien regresi variabel integritas adalah 0,597 artinya setiap kenaikan variabel integritas maka Kualitas Pemeriksaan akan meningkat sebesar 59,7\% dengan asumsi variabel lainnya dianggap konstan serta signifikansi variabel integritas menunjukkan nilai signifikansi 0,009 (Sig = $0,009<0,05)$ sehingga secara parsial variabel integritas berpengaruh signifikan terhadap Kualitas Pemeriksaan pada Perum Bulog Divisi Regional Sumatera Utara.Hasil 
penelitian tersebut sejalan dengan teori yang ada yang menyatakan bahwa integritas berpengaruh terhadap kualitas pemeriksaaan. Hal ini dapat diimplementasikan oleh Perum Bulog Divisi Regional Sumatera Utara untuk meningkatkan kualitas pemeriksaan yang dilakukan, yaitu dengan cara meningkatkan fakor integritas yang ada pada diri auditor yang dapat diwujudkan melalui bentuk kepatuhan kepada peraturan dan perundangan yang berlaku dalam melaksanakan seluruh proses dan tahapan audit. Hal ini dilakukan sebagai upaya menjaga tingkat integritas auditor Perum Bulog Divisi Regional Sumatera Utara.

\section{Pengaruh Akuntabilitas Audit terhadap Kualitas Pemeriksaan}

Hasil analisis regresi menunjukkan bahwa nilai koefisien regresi variabel akuntabilitas adalah 0,610 artinya setiap kenaikan variabel akuntabilitas maka Kualitas Pemeriksaan akan meningkat sebesar $61,0 \%$ dengan asumsi variabel lainnya dianggap konstan serta signifikansi variabel akuntabilitas menunjukkan nilai signifikansi 0,003 (Sig $=0,003<0,05)$ sehingga secara parsial variabel akuntabilitas berpengaruh signifikan terhadap Kualitas Pemeriksaan pada Perum Bulog Divisi Regional Sumatera Utara.Hasil penelitian ini konsisten dengan landasan teoritis dimana akuntabilitas berpengaruh terhaap kualitas pemeriksaaan. Hal ini dapat diimplementasikan oleh manajemen Perum Bulog Divisi Regional Sumatera Utara yaitu untuk meningkatkan kualitas pemeriksaan yang dilakukan maka hendaknya faktor akuntabilitas perlu untuk ditingkatkan juga. Upaya peningkatan akuntabilitas dapat dilakukan dengan cara mewujudkan tata kelola perusahaan yang baik (Good Corporate Governance) dalam organisasi, dimana salah satu prinsip utama Good Corporate Governance adalah akuntabilitas. Sehingga apabila Perum Bulog Divisi Regional Sumatera Utara mampu menerapkan Good Corporate Governance dalam organisasi, maka nilai-nilai akuntabilitas dapat tercipta di lingkungan organisasi tersebut.

\section{SIMPULAN}

Dari hasil pembahasan yang telah dijelaskan pada bab sebelumnya, maka dapat diambil kesimpulan bahwa secara parsial variabel objektivitas berpengaruh positif dan signifikan terhadap Kualitas Pemeriksaan Pada Perum Bulog Divisi Regional Sumatera Utara. Hal ini dibuktikan dari hasil pengujian parsial yang menunjukkan bahwa variabel Objektivitas signifikansi besar dari 0,05. Secara parsial juga variabel Kompetensi terhadap berpengaruh positif dan signifikan terhadap Kualitas Pemeriksaan Pada Perum Bulog Divisi Regional Sumatera Utara. Hal ini dibuktikan dari hasil pengujian parsial yang menunjukkan bahwa variabel Kompetensi $\left(\mathrm{X}_{2}\right)$ memiliki signifikansi 0,001 (Sig = $0,001<0,05$ ). Pengalaman Audit tidak berpengaruh secara parsial terhadap Kualitas Pemeriksaan Pada Perum Bulog Divisi Regional Sumatera Utara. Hal ini dibuktikan dari hasil pengujian parsial yang menunjukkan bahwa variabel Pengalaman Audit $\left(\mathrm{X}_{3}\right)$ memiliki signifikansi 0,247 (Sig $=0,247>0,05$ ). Secara parsial dapat dilihat Integritas berpengaruh positif dan signifikan terhadap Kualitas Pemeriksaan Pada Perum Bulog Divisi Regional Sumatera Utara. Hal ini dibuktikan dari hasil pengujian parsial yang menunjukkan bahwa variabel Integritas $\left(\mathrm{X}_{4}\right)$ memiliki signifikansi 0,009 (Sig =0,009 < 0,05). Serta akuntabilitas berpengaruh positif dan signifikan secara parsial terhadap Kualitas Pemeriksaan Pada Perum Bulog Divisi Regional Sumatera Utara. Hal ini dibuktikan dari hasil pengujian parsial yang menunjukkan bahwa variabel Akuntabilitas $\left(\mathrm{X}_{5}\right)$ memiliki signifikansi 0,003 (Sig =0,003 <0,05). Dari keseluruhan bersamaan secara Simultan Objektivitas, Kompetensi, Pengalaman Audit, Integritas dan Akuntabilitas berpengaruh positif dan signifikan terhadap Kualitas Pemeriksaan Pada Perum Bulog 
Divisi Regional Sumatera Utara. Hal ini dibuktikan dari hasil pengujian secara simultan yang menunjukkan nilai 0,000 (Sig $=0,000<0,05$ ). Dari beberapa simpulan tersebut dapat diambil saran yakni perusahaan perlu lebih meningkatkan kompetensi auditor agar dapat meningkatkan kualitas pemeriksaan. Hal ini dapat dilakukan auditor melalui bentuk pendidikan dan pelatihan yang dilakukan secara kontinu. Peneliti selanjutnya diharapkan menambah jumlah variabel independen lainnya seperti, etika, penggunaan teknologi dan tingkat pendidikan yang bisa saja mempengaruhi Kualitas Pemeriksaan. Serta, peneliti selanjutnya diharapkan menambah sampel data pengamatan.

\section{DAFTAR PUSTAKA}

Alim, M. Nizarul 2007, Pengaruh Kompetensi dan Independensi terhadap Kualitas Auditor dengan Etika auditor sebagai variabel moderasi, Simposium Nasional Akuntansi X.

Anestiani, Anggita Mela. (2017). Pengaruh Profesionalisme, Etika, Objektivitas, Independensi dan Kompetensi Auditor terhadap Kualitas Audit pada Kantor BPK RI Perwakilan Daerah Istimewa Yogyakarta. Surakarta: Jurnal Universitas Muhammadiyah Surakarta.

Arens, Alvin A., and J.K. Loebecke, 1996, Auditing : Pendekatan Terpadu, Adaptasi oleh Amir Abadi Yusuf, Buku Satu Salemba Empat, Jakarta. Arens dan Loebbecke. 2003. Auditing. Jakarta: Salemba empat.

Ashton, A.H. (1991). Experience and Error Frequency Knowledge as Potential Determinants of Audit Expertise. The Accounting Review, 66,2,218.

Asih, 2006. Faktor-faktor yang Mempengaruhi Kinerja Dibidang Auditing di Kantor Akuntan Publik (KAP) Propinsi Jawa Barat. Tesis S2 Program Pascasarjana UI, Jakarta.

Badan Urusan Logistik. (2016). Annual Report.

Budi Winarno. 2004. Kebijakan Publik : Teori dan Proses Edisi Revisi, Media Presindo. Yogyakarta.

Bonner, S.E., Lewis, B.L. (1990). Determinants of Auditor Expertise. Journal of Accounting Research, 28, 120

Badan Pemeriksa Keuangan, 2016. Ikhtisar Hasil Pemeriksaaan Semesteran.

De Angelo, LE. (1981). Auditor Size and Auditor Quality. Journal of Accounting and Economics, Dec, Vol.3, No.3:183-199

Deis, D.R. \& Giroux, G.A. (1992). Determinants of Audit Quality in the Public Sector. The Accounting Review, $67,3,462-479$

Departemen Keuangan (2008). Peraturan Menteri Keuangan No. 17/PMK.01/2008 tentang Jasa Akuntan Publik

Efendy, M. Taufiq. 2010. Pengaruh Kompetensi, Independensi,dan Motivasi Terhadap Kualitas Audit Aparat Inspektorat Dalam Pengawasan Keuangan Daerah. (Tesis). Semarang: Magister Sains Akuntansi Universitas Diponegoro Semarang.

Elfarini, Eunike Christina. (2007) Pengaruh Kompetensi Dan Independensi Auditor Terhadap Kualitas Audit (Studi Empiris Pada Kantor Akuntan Publik Di Jawa Tengah). Jurnal Universitas Negeri Semarang.

Efferin, Sujoko et all. 2008. Metode Penelitian Akuntansi.Bandung:Alfabeta

Financial Accounting Standards Board (FASB). (1980). Statement of Financial Accounting Concepts No.2: Qualitative Characteristics of Accounting Information. Stamford. Connecticut.

Gudono \& Murtanto, 1999. Identifikasi Karakteristik Keahlian Audit, Jurnal Riset Akuntansi Indonesia.

Hardiningsih, P. (2010). Pengaruh Independensi, Corporate Governance, Dan Kualitas Audit Terhadap Integritas Laporan Keuangan. Kajian Akuntansi, Vol. 2, No. 1.

Jusup, Al Haryono (2001). Dasar-Dasar Akuntansi Jilid 2. Yogyakarta : Bagian Penerbitan Sekolah Tinggi Ilmu YKPN.

Lubis, Haslinda, 2009, Pengaruh Keahlian, Independensi, Kecakapan Propesional dan Kepatuhan Kode Etik Terhadap Kualitas Auditor pada Inspektorat Sumatera Utara. Skripsi, Usu, Medan.

Mayangsari, S. (2003). Pengaruh Kualitas Audit, Independensi terhadap Integritas Laporan keuangan. Simposium Nasional Akuntansi VI. Surabaya.

Mardisar, Diani, dan Ria Nelly Sari. 2007. Pengaruh Akuntabilitas dan Pengetahuan terhadap Kualitas Hasil Kerja Auditor. SNA X Makassar. AUEP-11.

Mulyadi, (2002). Auditing. Buku Dua, Edisi Ke Enam, Penerbit : Salemba Empat, Jakarta.

Rahman, Ahmad Taufik. 2009. Persepsi Auditor Mengenai Pengaruh Kompetensi, Independensi, dan Due Professional Care terhadap Kualitas Audit. Skripsi. Fakultas Ekonomi Universitas Jenderal Soedirman. Purwokerto. 
Sawyer, Lawrence B, Dittenhofer Mortimer A, Scheiner James H. (2005). Internal Auditing. Diterjemahkan oleh : Ali Akbar, Jilid 3, Edisi 5, Salemba Empat : Jakarta.

Siregar, S., Fitriany, Aggrahita, V. (2009) Rotasi dan Kualitas Audit, Evaluasi atas Implementasi Kebijakan Menteri Keuangan KMK No. 423/KMK.06/2002 tentang Jasa Akuntan Publik, Hibah Fakultas Ekonomi Universitas Indonesia.

Sukriah, I, Akram, Inapty, B.a. 2009. Pengaruh Pengalaman Kerja, Independensi, Obyektivitas, Integritas, dan Kompetensi terhadap Kualitas Hasil Pemeriksaan. SNA XII Palembang.

Sukrisno, Agoes. 2004. Auditing (Pemeriksaan Akuntansi), Edisi Ketiga, Fakultas Ekonomi Universitas Indonesia; Jakarta.

Suraida, Ida. 2005. "Pengaruh Etika, Kompetensi, Pengalaman Audit dan Risiko Audit Terhadap Skeptisisme Profesional Auditor dan Ketepatan Pemberian Opini Akuntan Publik". Sosiohumaniora, Vol. 7 No. 3, November $2005: 186-202$.

Tetclock, P.E dan J.L. Kim. 1987. Accountability and judgment processes in a personality prediction task. Journal of Personality and Social psychology (April): 700-709.

Wibowo, A. Rossieta, H. (2009). Faktor-Faktor Determinan Kualitas Audit: Suatu Studi Dengan Pendekatan Earnings Surprise Benchmark. Seminar Nasional Akuntansi 12 Palembang

Wiratama, W. J. (2015). Pengaruh Independensi, Pengalaman Kerja, Due Professional Care dan Akuntanbilitas Terhadap Kualitas Audit. E-Jurnal Akuntansi Universitas Udayana.

Wijayanti, S., Candra, S., \& Sarjono, H. (2011). Analisis persediaan beras nasional dalam memenuhi kebutuhan beras nasional pada Perusahaan Umum Bulog. The Winners, 12(1), 82-96. . Undang-Undang Dasar Republik Indonesia Tahun 1945.

. Undang-Undang No. 7 Tahun 1996 Tentang Pangan 